\title{
Impact of intracerebroventricular obestatin on plasma acyl ghrelin, des-acyl ghrelin and nesfatin-1 levels, and on gastric emptying in rats
}

\author{
CHIH-YEN CHEN ${ }^{1,2}$, WEI-JEI LEE ${ }^{3}$, KEONG CHONG $^{4}$, SHOU-DONG LEE $^{1,2,5}$ and YOU-DI LIAO 6 \\ ${ }^{1}$ Division of Gastroenterology, Department of Medicine, Taipei Veterans General Hospital, Taipei; \\ ${ }^{2}$ National Yang-Ming University School of Medicine, Taipei; Departments of ${ }^{3}$ Surgery, and ${ }^{4}$ Internal Medicine, \\ Min-Sheng General Hospital, Taoyuan; ${ }^{5}$ Cheng Hsin General Hospital, Taipei; \\ ${ }^{6}$ Institute of Biomedical Sciences, Academia Sinica, Taipei, Taiwan
}

Received January 20, 2012; Accepted April 19, 2012

DOI: $10.3892 / \mathrm{mmr} .2012 .901$

\begin{abstract}
Obestatin, which is a putative 23-amino-acid peptide, is derived from the $\mathrm{C}$-terminal part of the mammalian preproghrelin gene. Nesfatin-1 mRNA is co-expressed with ghrelin in gastric endocrine X/A-like cells; therefore, nesfatin-1 may also interact with preproghrelin gene products in the stomach. In this study, we investigated the impact of obestatin on the plasma levels of acyl ghrelin, des-acyl ghrelin and nesfatin-1, and on the gastric emptying of a solid nutrient meal $2 \mathrm{~h}$ after an intracerebroventricular (ICV) injection in conscious, fasted rats. The rats were implanted with ICV catheters. Plasma levels of acyl ghrelin, des-acyl ghrelin and nesfatin-1, expected to be co-expressed with obestatin, were measured, whereas the human/rat corticotropin-releasing factor $(\mathrm{h} / \mathrm{rCRF})$ was applied as an inhibitor of gastric emptying. The ICV administration of obestatin (0.1, 0.3 and $1.0 \mathrm{nmol} / \mathrm{rat})$ did not modify the plasma acyl ghrelin and des-acyl ghrelin levels, the acyl ghrelin/ des-acyl ghrelin ratio and nesfatin- 1 concentrations. The ICV acute administration of obestatin had no influence on the 2-h rate of gastric emptying of a solid nutrient meal, but the ICV $\mathrm{h} / \mathrm{rCRF}$ injection delayed it. The weight of food ingested $1 \mathrm{~h}$ before ICV injection significantly, but negatively correlated with the gastric emptying of a solid nutrient meal. Our study indicates that the ICV injection of obestatin does not change the 2-h rate of gastric emptying of a solid nutrient meal and the relatively weak interrelationships between ghrelin gene products and nesfatin- 1 . However, the weight of the ingested food negatively affects the gastric emptying of a solid nutrient meal in conscious, fasted rats.
\end{abstract}

Correspondence to: Dr Chih-Yen Chen, Division of Gastroenterology, Taipei Veterans General Hospital, 201 Shih-Pai Road, Sec. 2, Taipei 112, Taiwan

E-mail: chency@vghtpe.gov.tw

Key words: gastric emptying, ghrelin, intracerebroventricular, nesfatin-1, obestatin

\section{Introduction}

Obestatin, a putative 23-amino-acid peptide, is derived from the C-terminal part of the mammalian preproghrelin gene via a bioinformatics approach (1). Originally projected as a rival of acyl ghrelin to counteract acyl ghrelin-induced orexigenic effects on food intake (1), obestatin has been suggested to bind to an orphan G-protein coupled receptor (GPR), termed GPR39, and increase intracellular cAMP levels (1). High levels of GPR39 mRNA have been found in the amygdala, hippocampus and auditory cortex, but not in the hypothalamus $(2,3)$. Previous studies have indicated that obestatin is not the endogenous cognate ligand for GPR39 (4-7), whereas only one study has suggested that a specific iodinated form of obestatin binds to GRP39 (8). If obestatin exists as an endogenous hormone, it most likely does not act through GPR39. The fact that the mRNA transcript of GPR39 has not been observed in the brain and that the antisense gene, LYDC, is highly expressed in the brain, suggests that GPR39 is critical for the functions of the liver, gastrointestinal tract, pancreas and white adipose tissue, but not for those of the brain (9). To date, the effects of obestatin on food intake remain debatable (10).

Obestatin has manifested various biological functions in the brain, e.g., the in vivo inhibition of thirst (11), increased non-rapid eye movement sleep episodes and decreased sleep latency (12), and improved memory retention and reduction of anxiety (13) in rats, as well as the in vitro activation of cortical neurons (14) and the stimulation of retinal pigment epithelial cell proliferation (15). Moreover, plasma obestatin levels are lower in obese (16), but higher in lean individuals (17), suggesting that obestatin may influence appetite and body composition in humans. Recent reports have revealed that plasma obestatin levels are lower in uremic patients than in healthy subjects, indicating that obestatin is implicated in the inflammatory state and in disturbances of the calcium/phosphate metabolism of hemodialysis patients $(17,18)$. Taken together, these emerging data imply that obestatin may play a role in metabolism (19). In addition, $c$-fos expression in the paraventricular nucleus has been shown to increase after the peripheral injection of obestatin in brain slides (20). Thus, in order to validate the evidence for and against the existence 
of obestatin as an endogenous hormone, further investigation is required. As feeding and gut motility are closely associated (21), a better understanding of the role of obestatin in gastric motility may help to elucidate its controversial function in feeding. Unfortunately, little information is available regarding the intracerebroventricular (ICV) influence on gastric emptying.

Aside from acyl ghrelin and des-acyl ghrelin, nesfatin-1 may also play a role in the stomach and may participate in active interactions with obestatin. Nesfatin-1/nucleobindin-2 mRNAs have been shown to be co-expressed with ghrelin in gastric endocrine cells (22). The interplay between either acyl ghrelin, des-acyl ghrelin or nesfatin-1 and obestatin is intriguing; however, the influence of ICV obestatin administration on the plasma levels of acyl ghrelin and des-acyl ghrelin, the acyl ghrelin/des-acyl ghrelin ratio and nesfatin-1 remains unknown. In the present study, we aimed to explore the ICV effects of obestatin on the plasma concentrations of acyl ghrelin, des-acyl ghrelin and nesfatin-1, and on the gastric emptying of a solid nutrient meal in conscious, fasted rats.

\section{Materials and methods}

Animals. Male Sprague-Dawley rats (National Laboratory Animal Center, Taipei, Taiwan), weighing 250-320 g at the initial period of the experiment, were used in group cages under controlled illumination (light cycle 08:00-20:00), humidity and temperature $\left(22.5 \pm 1.5^{\circ} \mathrm{C}\right)$ with free access to

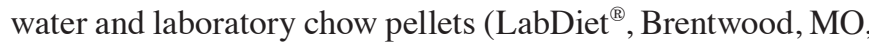
USA). All experiments were initiated at 8 a.m. in freely moving conscious, fed rats, according to guidelines approved by the Institutional Animal Care and Use Committee (IACUC) of the Taipei Veterans General Hospital, Taipei, Taiwan.

Surgery. ICV catheter implantation was performed as described previously $(23,24)$. Briefly, rats were anesthetized with an intraperitoneal injection of sodium pentobarbital (50 mg/kg, Nembutal; Abbott Laboratories, Abbott Park, IL, USA), placed in a stereotaxic apparatus and implanted with a guide cannula (25-gauge; Eicom, Kyoto, Japan) that reached the right lateral ventricle. Stereotaxic coordinates were $0.8 \mathrm{~mm}$ posterior to the bregma, $1.4 \mathrm{~mm}$ lateral to the midline and $4.5 \mathrm{~mm}$ below the outer surface of the skull using a stereotaxic frame (Benchmark ${ }^{\mathrm{TM}}$, myNeuroLab, St. Louis, MO, USA), with the incisor bar set at the horizontal plane passing through the bregma and lambda. The guide cannula was secured with dental cement anchored by two stainless steel screws fixed on the dorsal surface of the skull.

After surgery, a dummy cannula (Eicom) was inserted into each guide cannula. A screw cap (Eicom) was placed on the guide cannula to prevent blockage. Correctness of the ICV cannula placement was verified by injecting $100 \mu \mathrm{l}$ dye $(0.05 \%$ cresyl violet; Sigma) into the right lateral ventricle by the brain sections at the end of the experiments after euthanasia (25). Before beginning all food intake tests, the animals receiving an implantation of ICV catheters were allowed 7 days for recovery. All ICV injections were performed over a period of $60 \mathrm{sec}$ in $5 \mu \mathrm{l}$ using the AMI-5 (Eicom).

Preparation of drugs. Rat obestatin (Peptides International, Inc., Louisville, KY, USA) and human/rat corticotropin-releasing factor (h/rCRF) (American Peptide Company, Sunnyvale, CA, USA), were kept in powder form at $-20^{\circ} \mathrm{C}$ and dissolved in sterile, pyrogen-free $0.9 \%$ saline (Otsuka, Tokyo, Japan) immediately before use.

Measurement of plasma acyl ghrelin, des-acyl ghrelin and nesfatin-1. Blood samples were obtained following decapitation $2 \mathrm{~h}$ after the ICV injection. Each blood sample was immediately transferred to a chilled glass tube containing disodium ethylenediaminetetraacetic acid (EDTA) (1 mg/ $\mathrm{ml})$ and aprotinin $(500 \mathrm{U} / \mathrm{ml})$, and stored in an ice bath. After centrifugation at $300 \mathrm{x}$ g, the plasma was separated, dispensed into polypropylene tubes in aliquots and stored at $-20^{\circ} \mathrm{C}$ until analysis. Enzyme immunoassays (EIA) for plasma acyl ghrelin (SPI-Bio, Montigny le Bretonneux, France), des-acyl ghrelin (SPI-Bio) and nesfatin-1 (Phoenix Pharmaceuticals, Burlingame, CA, USA) were conducted in a single batch run and in a blinded fashion. The assay protocol was carried out as previously described, and the only difference was the primary antibody (26).

Gastric emptying of a solid nutrient meal. A gastric motility test was conducted as previously described (27). Light-phase experiments for the fasted rats were initiated at 8 a.m. Before the experiments, the rats were deprived of food for $16 \mathrm{~h}$ with free access to water. The fasted rats were given access to preweighed pellets $(350 \mathrm{kcal} / 100 \mathrm{~g}$ ) for $1 \mathrm{~h}$. One of the following was then injected ICV: vehicle (10 $\mu \mathrm{l}$ of saline), obestatin $(0.1$, 0.3 or $1 \mathrm{nmol} / \mathrm{rat})$ or $\mathrm{h} / \mathrm{rCRF}$ ( $1 \mathrm{nmol} / \mathrm{rat})$. After ICV injection, the rats were fasted for $2 \mathrm{~h}$. Food intake was calculated by subtracting the weight of the uneaten pellets from the weight of the pellets initially provided, and then split at the end of each time-point $(23,28)$.

The rats were decapitated $3 \mathrm{~h}$ after the start of the experiment. The stomach and attached small intestine were then immediately exposed by laparotomy. After ligating the esophago-gastric and gastro-duodenal junctions, the whole stomach was carefully mobilized. The gastric contents were dried using a vacuum freeze-drying system and weighed. Gastric emptying was calculated as: [1 - (dry weight of food in the stomach/ weight of food ingested)] x 100\%. The weight of food emptied into the duodenum was calculated as: weight of food ingested - dry weight of food in the stomach.

Statistical analysis. All results are expressed as the means \pm SEM. Correlations between gastric emptying, weight of food ingested and weight of food emptied into the duodenum were analyzed using Pearson's correlation test. One-way analysis of variance (ANOVA) followed by a Student-Newman-Keuls posthoc test were used to analyze the differences among the groups. Differences were considered statistically significant at $\mathrm{P}<0.05$.

\section{Results}

Effects of ICV obestatin injection on plasma acyl ghrelin, desacyl ghrelin, acyl ghrelin/des-acyl ghrelin ratio and nesfatin-1. Obestatin at 3 different doses (0.1, 0.3 and $1 \mathrm{nmol} / \mathrm{rat}) \mathrm{did}$ not change the plasma levels of acyl ghrelin and des-acyl ghrelin and the acyl ghrelin/des-acyl ghrelin ratio compared to the vehicle-injected controls $2 \mathrm{~h}$ after ICV injection (Fig. 1A-C). 
A
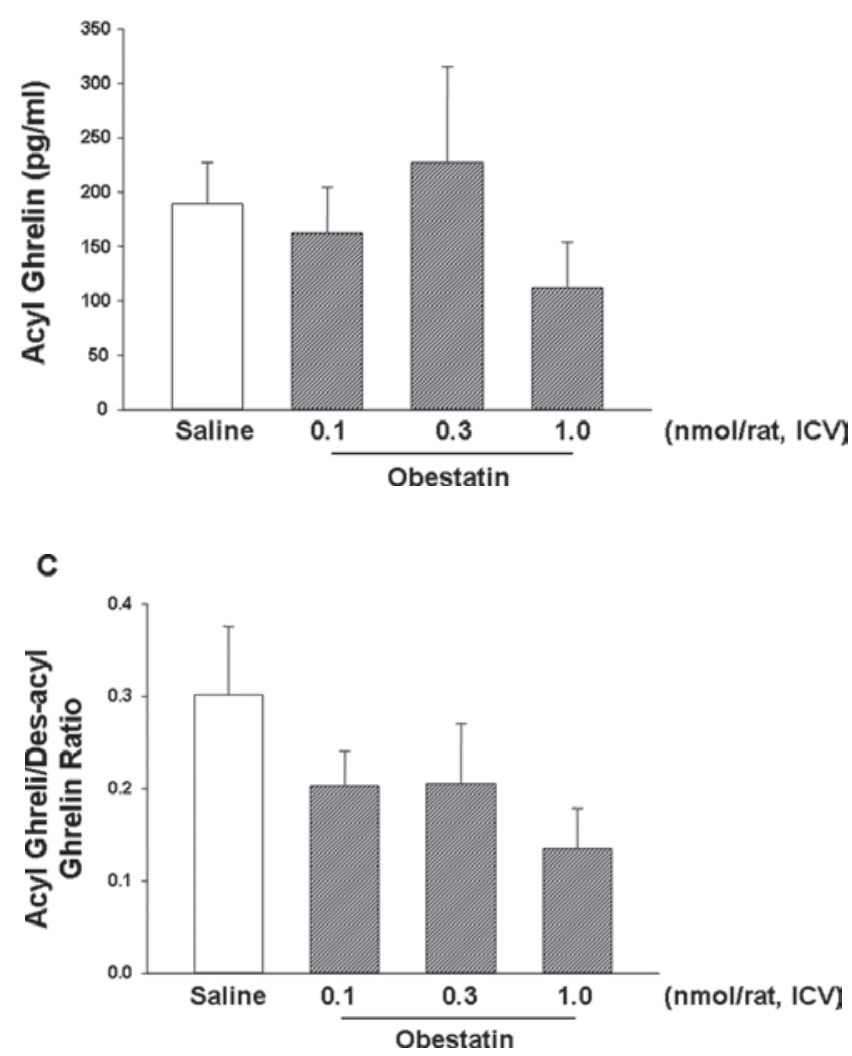

B

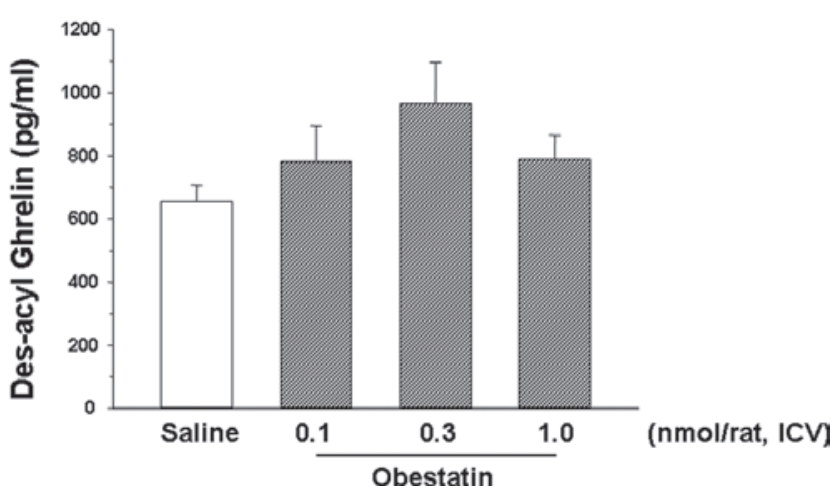

D

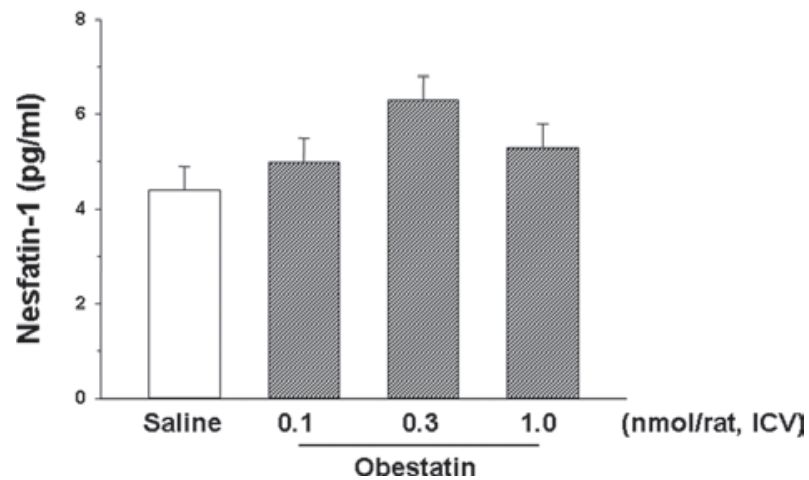

Figure 1. The influence of intracerebroventricular (ICV) injection of obestatin (0.1, 0.3 and $1.0 \mathrm{nmol} / \mathrm{rat}$ ) on plasma levels of (A) acyl ghrelin, (B) des-acyl ghrelin, (C) acyl ghrelin/des-acyl ghrelin ratio and (D) nesfatin-1 levels; $n=6$ rats in each group.

A

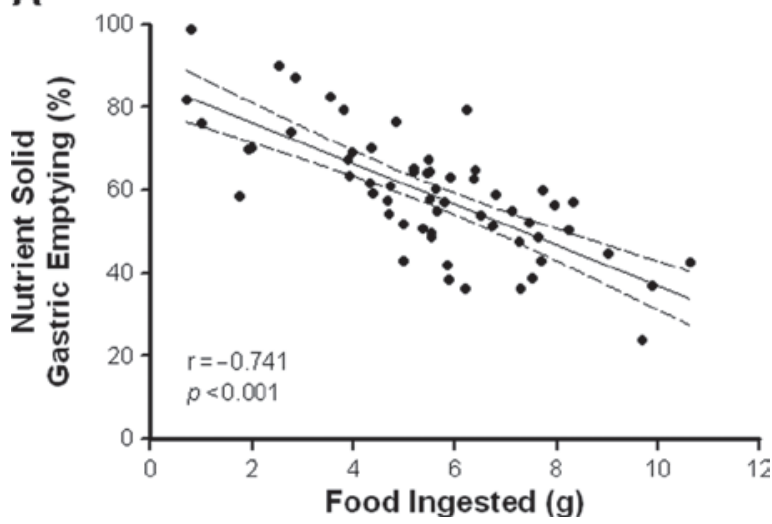

B

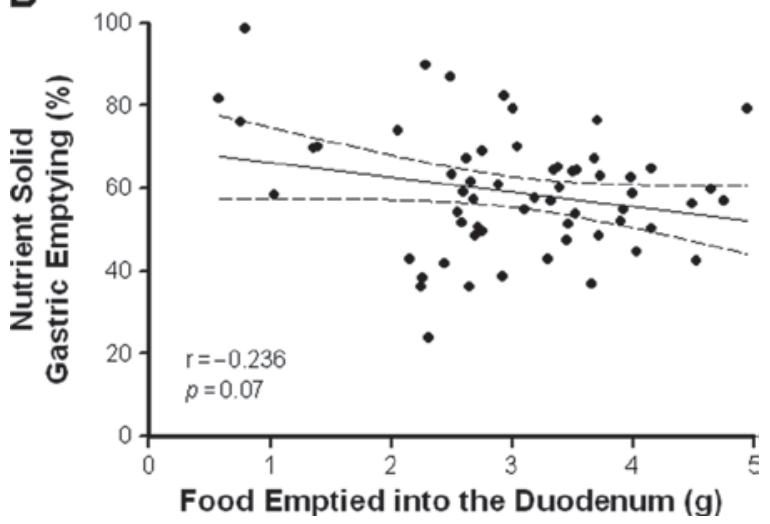

Figure 2. There was (A) a significant negative correlation between the gastric emptying of a solid nutrient meal and the weight of food ingested at $1 \mathrm{~h}$ before intracerebroventricular (ICV) injection $(\mathrm{r}=-0.741, \mathrm{P}<0.001)$, and $(\mathrm{B})$ a tendency of negative correlation observed between the gastric emptying of a solid nutrient meal and the weight of food emptied into the duodenum $2 \mathrm{~h}$ after ICV injection ( $\mathrm{r}=-0.236, \mathrm{P}=0.07) ; \mathrm{n}=60 \mathrm{rats}$ total.

Obestatin at these doses did not affect the plasma nesfatin-1 concentration $2 \mathrm{~h}$ after ICV injection (Fig. 1D).

Effects of the weight of food ingested and that of food emptied into the duodenum on gastric emptying of a solid nutrient meal. Our results showed that there was a significant, but negative correlation between the gastric emptying of a solid nutrient meal and the weight of food ingested (Fig. 2A). The gastric emptying of a solid nutrient meal revealed only a tendency for correlation with the weight of food emptied into the duodenum $2 \mathrm{~h}$ after ICV injection (Fig. 2B). In addition, the 2-h rate of gastric emptying of a solid nutrient meal significantly, but negatively correlated with the amount of calories ingested $(\mathrm{kcal} / \mathrm{h})(\mathrm{r}=-0.741, \mathrm{P}<0.001)$.

Effects of ICV obestatin and $h / r C R F$ on gastric emptying of a solid nutrient meal. Obestatin (0.1, 0.3 and $1 \mathrm{nmol} / \mathrm{rat}) \mathrm{did}$ not accelerate or delay the gastric emptying of a solid nutrient meal compared to the vehicle-injected controls $2 \mathrm{~h}$ after ICV injection in conscious, fasted rats (Fig. 3A). By contrast, h/rCRF (1 nmol/ 

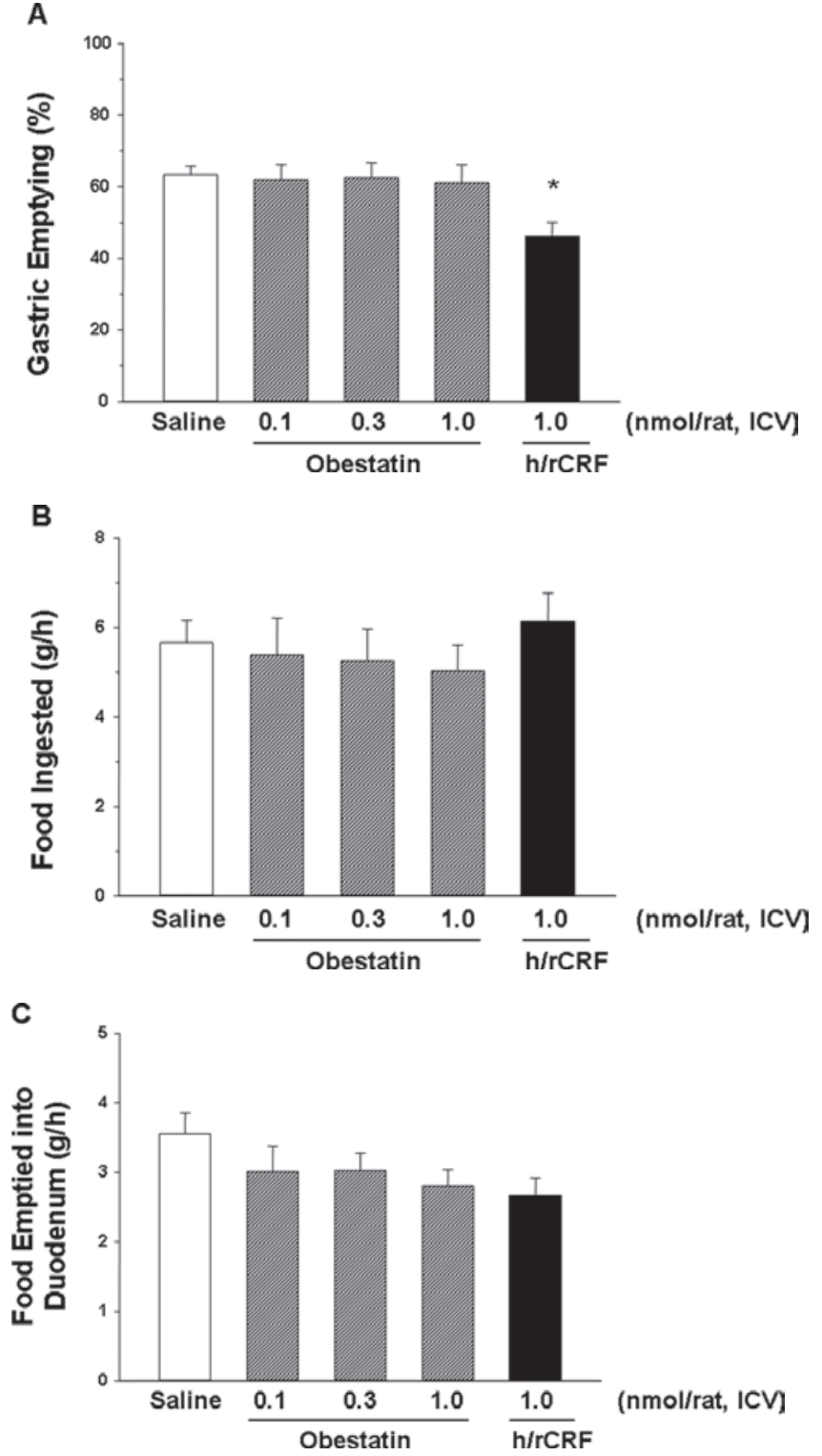

Figure 3. The gastric emptying of a solid nutrient meal, food ingested and food emptied into the duodenum in groups treated with intracerebroventricular (ICV) injection of either obestatin, or human/rat corticotropin-releasing factor (h/rCRF). (A) ICV obestatin $(0.1,0.3$ and $1.0 \mathrm{nmol} / \mathrm{rat})$ did not modify the gastric emptying of a solid nutrient meal, whereas $\mathrm{h} / \mathrm{rCRF}(1.0 \mathrm{nmol} / \mathrm{rat})$ significantly delayed it ( $\mathrm{P}<0.05$ compared to all the other groups, $\mathrm{n}=12$ rats in each group). (B) Ingested food and (C) food emptied into the duodenum were comparable among the different treatment groups $(n=12$ rats in each treatment group).

rat) significantly delayed the gastric emptying of a solid nutrient meal compared to the vehicle-injected controls (Fig. 3A). However, the weight of food ingested $1 \mathrm{~h}$ before and that of food emptied into the duodenum $2 \mathrm{~h}$ after ICV injection was comparable among the different groups (Fig. 3B and C).

\section{Discussion}

Previous studies have only measured the effects of obestatin on pituitary hormones and hypothalamic neuropeptides. For instance, obestatin does not affect the secretion of growth hormone, thyroid-stimulating hormone and adrenocorticotropic hormone, or the mRNA expression of neuropeptide Y, agouti-related protein, cocaine- and amphetamine-regulated transcript, and pro-opiomelanocortin, through either intravenous or ICV administration (29-31).

On the one hand, the influence of obestatin on other plasma hormones, such as acyl ghrelin, des-acyl ghrelin and nesfatin-1, has not yet been well addressed. Des-acyl ghrelin is the major molecular form circulating in the blood (32-34) that can be converted to acyl ghrelin through ghrelin $O$-acyltransferase in the stomach, intestine and pancreas $(35,36)$. Both the acyl and des-acyl forms of ghrelin are actively involved in the regulation of appetite, gut motility and energy homeostasis (21).

On the other hand, nesfatin-1 is a novel 82-amino-acid peptide, identified as a satiety signal encoded by nucleobindin-2 gene (37). Recent studies have indicated that nesfatin-1 is co-localized with ghrelin in rat gastric oxyntic mucosa. It is postulated to interact with ghrelin gene products to modulate food intake and body weight $(22,37)$. The interplay between obestatin and acyl ghrelin, des-acyl ghrelin, as well as nesfatin-1 is interesting, but is not yet well recognized. In patients with restricting-type anorexia nervosa, obestatin, as well as acyl ghrelin, des-acyl ghrelin and nesfatin-1, are important regulators responsive to starvation and re-nutrition (38). Following a PubMed search, the current study is the first to explore the impact of ICV obestatin on these above-mentioned peptides. The results from our study show that obestatin at the doses tested, does not affect the plasma levels of acyl ghrelin and des-acyl ghrelin, the acyl ghrelin/des-acyl ghrelin ratio and nesfatin-1 $2 \mathrm{~h}$ after ICV injection.

Previous studies have only focused on the effects of peptide administration on the gastric emptying of a solid nutrient meal in mice (27) and rats (39). Little attention has been paid to the influence of the weight of food ingested and that of food emptied into the duodenum on gastric emptying. The results from our study reveal that the weight of food ingested negatively, but significantly correlates with the gastric emptying of a solid nutrient meal, whereas the weight of food emptied into the duodenum has a tendency for negative correlation. Thus, the weight of food ingested should be cautiously taken into consideration before data interpretation using models of gastric emptying of a solid nutrient meal in the future.

The first preproghrelin gene product, acyl ghrelin, induces prokinetic activity along the entire gastrointestinal tract (40-43). When administered through ICV or intravenous injection, acyl ghrelin has been shown to accelerate the gastric emptying of a solid nutrient meal in fasted mice (44) and the gastric emptying of a non-nutrient, semi-liquid meal in fasted rats (25). It also elicits phase III-like contractions in the duodenum in acutely fed rats (45). The second ghrelin gene product, desacyl ghrelin, via central or peripheral administration, has been shown to delay the gastric emptying of a solid nutrient meal in fasted mice (46) and to disrupt phase III-like contractions in the antrum in fasted rats (23).

In the present study, we examined the influence of the third preproghrelin gene product, obestatin, on the gastric emptying of a solid nutrient meal in rats. By contrast, unlike acyl ghrelin and/or des-acyl ghrelin, the ICV injection of obestatin $(0.1-1.0 \mathrm{nmol})$, did not modify the gastric emptying of a solid nutrient meal in this study. Although GPR39 mRNA is abundant in the amygdala, hippocampus and auditory cortex $(2,3)$, and obestatin is capable of binding to GRP39 to regulate 
the functions of diverse gastrointestinal and adipose tissues (8), the current results suggest that obestatin does not act in the forebrain to affect the gastric emptying of a solid nutrient meal in conscious, fasted rats.

The findings from our study are comparable to those from a previous report measuring intra-gastric pressure after an intracisternal injection (hindbrain) of obestatin at higher doses (7.5 and $30 \mu \mathrm{g} / \mathrm{rat}$ ) via an acutely implanted catheter in anesthetized rats (47). However, an intra-arcuate nucleus injection of obestatin has been shown to inhibit dopamine release and block the ghrelin-induced inhibition of serotonin release in the rat hypothalamus (48). Recent studies have revealed that manometric recording is a more sensitive way than gastric emptying measurement in detecting gastro-inhibitory effects of presumed anorectic peptides $(28,49)$. Furthermore, the intravenous infusion of obestatin has been clearly shown to inhibit the percentage motor index and phase III-like contractions in the antrum and duodenum in conscious, fed rats (50). Studies using manometric methods to investigate the central effects of obestatin on gastric motility are warranted in the future.

The peripheral administration of obestatin reportedly alters gastroduodenal motility via CRF receptors $(20,50)$. As such, $\mathrm{h} / \mathrm{rCRF}$ has been used as the inhibitory control for comparison in this study. From the data obtained, it is evident that an ICV injection of $\mathrm{h} / \mathrm{rCRF}(1 \mathrm{nmol})$ significantly delays gastric emptying of a solid nutrient meal, which is consistent with a previous report that used gastric emptying of a non-nutrient, semi-liquid meal through intracisternal administration (51). Although the half-life of $\mathrm{h} / \mathrm{rCRF}$ is reportedly less than $10 \mathrm{~min}$ in human cerebrospinal fluid (52), the results from our current study show that the ICV h/rCRF injection ( $1 \mathrm{nmol}$ ) effectively inhibits the 2 -h rate of gastric emptying of a solid nutrient meal in conscious, fasted rats.

In summary, obestatin at the doses tested does not change the plasma acyl ghrelin and des-acyl ghrelin levels, the acyl ghrelin/des-acyl ghrelin ratio and nesfatin-1 levels $2 \mathrm{~h}$ after ICV injection. The acute ICV administration of obestatin has no influence on the 2-h rate of gastric emptying of a solid nutrient meal in conscious, fasted rats, whereas ICV h/rCRF injection delays it. The weight of food ingested negatively affects the gastric emptying of a solid nutrient meal.

\section{Acknowledgements}

This study was supported by grants from the National Science Council (NSC 94-2314-B-075-008- and NSC 99-2314-B-010-016-MY2 to C.Y.C.), and partly by Academia Sinica (IBMS-CRC93-V01 to C.Y.C. and Y.D.L.), Taiwan. The authors thank Miss Tiffany $C$. Lee for her secretarial assistance in manuscript editing. The authors acknowledge the help from Dr Chi Chin-Wen, Miss Hung Mei-Whey and the Clinical Research Core Laboratory, Taipei Veterans General Hospital.

\section{References}

1. Zhang JV, Ren PG, Avsian-Kretchmer O, et al: Obestatin, a peptide encoded by the ghrelin gene, opposes ghrelin's effects on food intake. Science 310: 996-999, 2005.

2. Jackson VR, Nothacker HP and Civelli O: GPR39 receptor expression in the mouse brain. Neuroreport 17: 813-816, 2006.
3. McKee KK, Tan CP, Palyha OC, et al: Cloning and characterization of two human $\mathrm{G}$ protein-coupled receptor genes (GPR38 and GPR39) related to the growth hormone secretagogue and neurotensin receptors. Genomics 46: 426-434, 1997.

4. Lauwers E, Landuyt B, Arckens L, Schoofs L and Luyten W: Obestatin does not activate orphan $\mathrm{G}$ protein-coupled receptor GPR39. Biochem Biophys Res Commun 351: 21-25, 2006.

5. Holst B, Egerod KL, Schild E, et al: GPR39 signaling is stimulated by zinc ions but not by obestatin. Endocrinology 148: 13-20, 2007.

6. Chartrel N, Alvear-Perez R, Leprince J, et al: Comment on 'obestatin, a peptide encoded by the ghrelin gene, opposes ghrelin's effects on food intake'. Science 315: 766, 2007.

7. Zhang JV, Klein C, Ren PG, et al: Response to comment on 'obestatin, a peptide encoded by the ghrelin gene, opposes ghrelin's effects on food intake'. Science 315: 766d, 2007.

8. Zhang JV, Jahr H, Luo CW, et al: Obestatin induction of earlyresponse gene expression in gastrointestinal and adipose tissues and the mediatory role of G protein-coupled receptor, GPR39. Mol Endocrinol 22: 1464-1475, 2008.

9. Egerod KL, Holst B, Petersen PS, Hansen JB, Mulder J, Hökfelt T and Schwartz TW: GPR39 splice variants versus antisense gene LYPD1: expression and regulation in gastrointestinal tract, endocrine pancreas, liver, and white adipose tissue. Mol Endocrinol 21: 1685-1698, 2007.

10. Chen CY, Fujimiya M, Asakawa A, Chang FY, Cheng JT, Lee SD and Inui A: At the cutting edge: ghrelin gene products in food intake and gut motility. Neuroendocrinology 89: 9-17, 2009.

11. Samson WK, White MM, Price C and Ferguson AV: Obestatin acts in brain to inhibit thirst. Am J Physiol Regul Integr Comp Physiol 292: R637-R643, 2007.

12. Szentirmai E and Krueger JM: Obestatin alters sleep in rats. Neurosci Lett 404: 222-226, 2006.

13. Carlini VP, Schiöth HB and Debarioglio SR: Obestatin improves memory performance and causes anxiolytic effects in rats. Biochem Biophys Res Commun 352: 907-912, 2007.

14. Dun SL, Brailoiu GC, Brailoiu E, Yang J, Chang JK and Dun NJ: Distribution and biological activity of obestatin in the rat. J Endocrinol 191: 481-489, 2006.

15. Camiña JP, Campos JF, Caminos JE, Dieguez C and Casanueva FF: Obestatin-mediated proliferation of human retinal pigment epithelial cells: regulatory mechanisms. J Cell Physiol 211: 1-9, 2007.

16. Zhang N, Yuan C, Li Z, et al: Meta-analysis of the relationship between obestatin and ghrelin levels and the ghrelin/obestatin ratio with respect to obesity. Am J Med Sci 341: 48-55, 2011.

17. Mafra D, Guebre-Egziabher F, Cleaud C, Arkouche W, Mialon A, Drai J and Fouque D: Obestatin and ghrelin interplay in hemodialysis patients. Nutrition 26: 1100-1104, 2010.

18. Lacquaniti A, Bolignano D, Donato V, Chirico V, Romeo A, Loddo S and Buemi M: Obestatin: a new element for mineral metabolism and inflammation in patients on hemodialysis. Kidney Blood Press Res 34: 104-110, 2011.

19. Li JB, Asakawa A, Cheng K, Li Y, Chaolu H, Tsai M and Inui A: Biological effects of obestatin. Endocrine 39: 205-211, 2011.

20. Fujimiya M, Asakawa A, Ataka K, Chen CY, Kato I and Inui A: Ghrelin, des-acyl ghrelin and obestatin: regulatory roles on the gastrointestinal motility. Int J Pept 2010: pii: 305192, 2010.

21. Chen CY, Asakawa A, Fujimiya M, Lee SD and Inui A: Ghrelin gene products and the regulation of food intake and gut motility. Pharmacol Rev 61: 430-481, 2009.

22. Stengel A, Goebel M, Yakubov I, et al: Identification and characterization of nesfatin-1 immunoreactivity in endocrine cell types of the rat gastric oxyntic mucosa. Endocrinology 150: 232-238, 2009.

23. Chen CY, Inui A, Asakawa A, et al: Des-acyl ghrelin acts by CRF type 2 receptors to disrupt fasted stomach motility in conscious rats. Gastroenterology 129: 8-25, 2005.

24. Chen CY, Tsai CY, Lee WJ, Liaw WJ, Chiang CH, Ho ST and Lee SD: Intracerebroventricular O-n-octanoylated ghrelin and its splice variant-induced feeding is blocked by insulin, independent of obestatin or CRF receptor, in satiated rats. Nutrition: Mar 30, 2012 (Epub ahead of print). doi:10.1016/j.nut.2011.11.021.

25. Chen CY, Doong ML, Chien EJ, et al: Intracerebroventricular ghrelin enhances non-nutrient semiliquid gastric emptying in fasted conscious rats. Gastroenterol J Taiwan 25: 242-248, 2008.

26. Lee WJ, Chen CY, Chong K, Lee YC, Chen SC and Lee SD: Changes in postprandial gut hormones after metabolic surgery: a comparison of gastric bypass and sleeve gastrectomy. Surg Obes Relat Dis 7: 683-690, 2011. 
27. Ushikai M, Asakawa A, Sakoguchi T, Tanaka $\mathrm{C}$ and Inui $\mathrm{A}$ Centrally administered urocortin 3 inhibits food intake and gastric emptying in mice. Endocrine 39: 113-117, 2011.

28. Atsuchi K, Asakawa A, Ushikai M, et al: Centrally administered neuromedin $\mathrm{S}$ inhibits feeding behavior and gastroduodenal motility in mice. Horm Metab Res 42: 535-538, 2010.

29. Nogueiras R, Pfluger P, Tovar S, et al: Effects of obestatin on energy balance and growth hormone secretion in rodents. Endocrinology 148: 21-26, 2007.

30. Zizzari P, Longchamps R, Epelbaum J and Bluet-Pajot MT: Obestatin partially affects ghrelin stimulation of food intake and growth hormone secretion in rodents. Endocrinology 148: 1648-1653, 2007.

31. Yamamoto D, Ikeshita N, Daito R, et al: Neither intravenous nor intracerebroventricular administration of obestatin affects the secretion of GH, PRL, TSH and ACTH in rats. Regul Pept 138: 141-144, 2007.

32. Garcia JM, Garcia-Touza M, Hijazi RA, et al: Active ghrelin levels and active to total ghrelin ratio in cancer-induced cachexia. J Clin Endocrinol Metab 90: 2920-2926, 2005.

33. Hosoda H, Kojima M, Matsuo H and Kangawa K: Ghrelin and des-acyl ghrelin: two major forms of rat ghrelin peptide in gastrointestinal tissue. Biochem Biophys Res Commun 279: 909-913, 2000

34. Yoshimoto A, Mori K, Sugawara A, et al: Plasma ghrelin and desacyl ghrelin concentrations in renal failure. J Am Soc Nephrol 13: 2748-2752, 2002.

35. Yang J, Brown MS, Liang G, Grishin NV and Goldstein JL: Identification of the acyltransferase that octanoylates ghrelin, an appetite-stimulating peptide hormone. Cell 132: 387-396, 2008.

36. Gutierrez JA, Solenberg PJ, Perkins DR, et al: Ghrelin octanoylation mediated by an orphan lipid transferase. Proc Nat Acad Sci USA 105: 6320-6325, 2008.

37. Stengel A, Goebel M, Wang L and Taché Y: Ghrelin, des-acyl ghrelin and nesfatin-1 in gastric X/A-like cells: role as regulators of food intake and body weight. Peptides 31: 357-369, 2010.

38. Ogiso K, Asakawa A, Amitani H, et al: Plasma nesfatin-1 concentrations in restricting-type anorexia nervosa. Peptides 32 : 150-153, 2011

39. Chen CY, Million M, Adelson DW, Martínez V, Rivier J and Taché Y: Intracisternal urocortin inhibits vagally stimulated gastric motility in rats: role of CRF2. Br J Pharmacol 136 237-247, 2002
40. Chen CY, Fujimiya M, Asakawa A, Lee SD and Inui A: Regulation of ingestive behavior, the upper gastrointestinal motility and gastric acid secretion by ghrelin in mammals. Curr Nutr Food Sci 4: 32-40, 2008.

41. Chen CY, Fujimiya M, Laviano A, Chang FY, Lin HC and Lee SD: Modulation of ingestive behavior and gastrointestinal motility by ghrelin in diabetic animals and humans. J Chin Med Assoc 73: 225-229, 2010.

42. Chen CY and Tsai CY: Ghrelin and motilin in the gastrointestinal system. Curr Pharm Des, 2012 (In press).

43. Chen CY and Huang SC: Lack of direct effects of acyl ghrelin, des-acyl ghrelin, and obestatin on rat lower esophageal sphincter motility in vitro. J Chin Med Assoc 74: 394-399, 2011

44. Asakawa A, Inui A, Kaga T, et al: Ghrelin is an appetite-stimulatory signal from stomach with structural resemblance to motilin. Gastroenterology 120: 337-345, 2001.

45. Fujino K, Inui A, Asakawa A, Kihara N, Fujimura M and Fujimiya M: Ghrelin induces fasted motor activity of the gastrointestinal tract in conscious fed rats. J Physiol 550: 227-240, 2003.

46. Asakawa A, Inui A, Fujimiya M, et al: Stomach regulates energy balance via acylated ghrelin and desacyl ghrelin. Gut 54: 18-24, 2005.

47. Gourcerol G, Coskun T, Craft LS, et al: Preproghrelin-derived peptide, obestatin, fails to influence food intake in lean or obese rodents. Obesity 15: 2643-2652, 2007.

48. Brunetti L, Di Nisio C, Recinella L, et al: Obestatin inhibits dopamine release in rat hypothalamus. Eur J Pharmacol 641: 142-147, 2010.

49. Atsuchi K, Asakawa A, Ushikai M, et al: Centrally administered nesfatin-1 inhibits feeding behaviour and gastroduodenal motility in mice. Neuroreport 21: 1008-1011, 2010.

50. Ataka K, Inui A, Asakawa A, Kato I and Fujimiya M: Obestatin inhibits motor activity in the antrum and duodenum in the fed state of conscious rats. Am J Physiol Gastrointest Liver Physiol 294: G1210-G1218, 2008.

51. Czimmer J, Million M and Taché Y: Urocortin 2 acts centrally to delay gastric emptying through sympathetic pathways while CRF and urocortin 1 inhibitory actions are vagal dependent in rats. Am J Physiol Gastrointest Liver Physiol 290: G511-G518, 2006.

52. Geracioti TD Jr, Orth DN, Ekhator NN, Blumenkopf B and Loosen PT: Serial cerebrospinal fluid corticotropin-releasing hormone concentrations in healthy and depressed humans. J Clin Endocrinol Metab 74: 1325-1330, 1992. 